\title{
Analysis of the factors that affect competitiveness of a supplier in the oil sector, in the state of Tabasco, generating a development proposal
}

\section{Análisis de los factores que inciden en la competitividad de una empresa proveedora de insumos en el sector petrolero, en el estado de Tabasco, generando una propuesta de desarrollo}

\author{
ELISEO-DANTÉS, Hortensia†*, MOREJÓN-SÁNCHEZ, Juana María, PÉREZ-PÉREZ, Iris Cristel \\ and GARCÍA-REYES, David Antonio
}

Tecnológico Nacional de México / ITVillahermosa

ID $1^{\text {st }}$ Author: Hortensia, Eliseo-Dantés / ORC ID: 0000-0003-4006-4669, Researcher ID Thomson: F-6749-2018, CVU CONACYT ID: 411079

ID $1^{\text {st }}$ Coauthor: Juana María, Morejón-Sánchez / ORC ID: 0000-0002-9930-181X, CVU CONACYT ID: 362413

ID $2^{\text {nd }}$ Coauthor: Iris Cristel, Pérez-Pérez / ORC ID: 0000-0003-3120-5597, Researcher ID Thomson: G-1891-2018, CVU CONACYT ID: 843577

ID $3^{\text {rd }}$ Coauthor: David Antonio, García-Reyes / ORC ID: 0000-0002-6083-079X, Researcher ID Thomson: D-4836-2018, CVU CONACYT ID: 883868

\begin{abstract}
Objective: To detect the factors which affect competitiveness of the hydrocarbon sector from the study context. In order to generate a proposal for the improvement of that sector. Methodology. Through working with experts, it is possible to interrelate information that allows visualizing in a global way the study problem. This is achieved through the study of the context variables (six), with support from the structural analysis scheme that will generate the four potential areas where the conflict zone, power zone, zone of autonomous problems and exit zone are located, allowing the clear detection of the incident factors. Results. Given the previous scheme and with an in-depth analysis, we propose a model that generates the strengthening of the key factors (power zone), also we search for a way to stabilize the factors of the zone of conflict; all this will consolidate the work of the type of organizations studied, enabling them to be competitive in a globalized environment.
\end{abstract}

Competitiveness, Context variables, key factors

\begin{abstract}
Resumen
Objetivo: Lograr detectar del contexto de estudio los factores que están incidiendo en la competitividad del importante sector de hidrocarburos. Con la finalidad de generar una propuesta de mejora para dicho sector. Metodología. A través del trabajo con expertos se logra interrelacionar información que permite visualizar de manera global el problema de estudio. Esto es a través del estudio de las variables del contexto (seis), con apoyo del esquema del análisis estructural que generará las cuatro áreas potenciales donde se encuentran la zona de conflictos, zona de poder, zona de problemas autónomos y zona de salida, permitiendo la detección clara de los factores incidentes. Resultados. Dado el esquema anterior y con un análisis a profundidad permite el poder proponer un modelo que genere el fortalecimiento de los factores claves (zona de poder), también buscar una ruta para la estabilidad de los factores de la zona de conflicto, todo ello vendrá a consolidar el trabajo del tipo de organizaciones estudiadas que les permite ser competitivas en un ámbito globalizado.
\end{abstract}

Competitividad, Variables del contexto, Factores claves

Citation: ELISEO-DANTÉS, Hortensia, MOREJÓN-SÁNCHEZ, Juana María, PÉREZ-PÉREZ, Iris Cristel and GARCÍAREYES, David Antonio. Analysis of the factors that affect competitiveness of a supplier in the oil sector, in the state of Tabasco, generating a development proposal. Rinoe Journal-Industrial Organization. 2019. 3-4:1-6.

$\dagger$ Researcher contributing first author. 


\section{Introduction}

In recent times, the economic model of developed countries has migrated to the knowledge industry, which determines as its competitive strength intangible assets, comprised of people's knowledge, attitudes, values and skills. The increasing value of these assets as key products for the economy and society is due, largely, to current international conditions. That is, organizations generate value, according to Drucker (2006), based on their ability to manage knowledge, thereby obtaining a competitive advantage in the globalized market.

Since the intangible resources of companies involve the competences of people and the results obtained from them, the complexity of their management and control increases considerably, because, although it is a capital that the company has, it is not property of the organization as such, rather, it hires the use of said capital through its collaborators. In this context, and in order to direct the present investigation towards aspects related to obtaining intellectual capital in organizations, the need arises to develop a formal scheme.

Intellectual capital, in this sense, encompasses the intangible resources of the organization in three fundamental dimensions: human capital, relative to the competences of employees; structural capital, related to intangible assets that are owned by the organization; and social capital, which refers to the company's relationships with customers, suppliers, etc. It is important to mention that it is called capital because its origin come from economic sciences, and so, the scholars committed to the growth of profits in companies identified the potential of intangible resources to generate economic value to organizations.

\section{Background}

Although the country's competitive backwardness is attributed to the competitive disadvantage facing international markets, the main problem of Mexican companies is the difficulty of adapting to change, that is, the lack of flexibility in organizational structures, which keeps them rigid, obsolete and unable to face the challenges of a rapidly changing context.
In this sense, the reactivity of the productive sectors of the country has resulted in a deficient operability, causing the shortage of teleological culture and organizational prospective, aspects that are characteristic of the human factor.

The foregoing becomes very important, since, according to Villegas, Hernández and Salazar (2015, p. 204) "it has been proven that human capital is the main source of intellectual capital and factor of creation of added value that transcends in the companies of the industrial sector in Mexico." Their work also showed that intellectual capital positively affects key elements for organizations, such as financial profitability, market capitalization and the level of value of the share.

In this sense, Mexican companies face the loss of their competitive capacity due to their deficit to obtain intellectual capital, as noted by Joya, Gámez, Ortiz and Gálvez (2015, p. 91) in their study focused on $19.7 \%$ of the total of companies that have failed between the years 2010-2015, from the state of Jalisco. In their study, they describe that organizations are not aware of the value generated by intellectual capital; therefore they do not encourage collaborative work, nor the development of their collaborators, coupled with the inflexible structure they manage, which makes effective anticipation impossible before context changes.

Intangible assets are considered by managers as essential for achieving organizational objectives; however, of the three dimensions that make up intellectual capital, the human capital and structural capital need to be strengthened, mainly in relation to the training of personnel regarding information technologies, as well as in the investment in information equipment and systems. (Larios, 2009).

Simó and Sallán (2008, p. 74-76) affirm the need to develop methodologies for assessing knowledge both implicitly and explicitly, because they create value in organizations to measure and evaluate their intellectual capital, since they would be able to evaluate their background and relationship with the results, which are considered as other intangible assets. 


\section{Problem Statement}

At present, the main economic activity of the state of Tabasco is oil mining, with a contribution of $54.1 \%$ to the state GDP in 2016 (SE, 2017). Tabasco is the second state nationwide which, after the state of Campeche ( $80.9 \%$ of state GDP), depends the most on the oil industry, an aspect that triggered the economic recession of both states in the period 2016-2018. However, at the end of 2018, there has been a slight recovery in the oil sector.The above suggests that the economic dependence of the state of Tabasco on the hydrocarbons sector has generated stagnation in the organizational structures of the companies belonging to the industry, which suffered the abrupt consequences of the economic crisis in the past years, causing their extinction or reduction in size, as they were unable to anticipate the aforementioned event.

Given the international trend of migrating to the knowledge industry and the value that this transition has generated according to various studies in different productive sectors, large transnational industries have taken competitive advantage over Mexican companies, causing in the worst case scenario, their extinction. This is a result of their lack of solvency in economic, technological and strategic terms to meet the demands of the market. (Larios, 2009; Joya et. Al., 2015; Beurregard, 2015). The main challenges for companies in the field of intellectual capital are, according to Ramírez considers (2007, p. 151), first of all, the need to improve the tools for managing investment in employee skills, databases and technological capabilities, as well as the accounting-type measurement of intangible assets, so that the difference between companies where intellectual capital can be seen in contrast to which this asset is neglected can be reliably verified. Finally, the ability to measure long-term returns on investment in people, skills and other intangible assets.

Based on this and on the theoretical basis of the present work, we assert that the use of the immaterial resources available in Mexican organizations, which represent the means to generate wealth in the future, is not managed efficiently and, in some cases, it is even null. This is an alarming aspect, considering that intellectual capital is the engine of productive force that brings greater value to the companies of first world countries.

\section{International context}

According to the U.S. Energy Information Administration (2018), 127 countries extract crude oil and 95 dry natural gas; the United States being the main supplier in both cases, as shown in Tables 1 and 2.

\begin{tabular}{|l|r|r|r|}
\hline $\mathbf{N}^{\mathbf{c}}$ Coauntry & \multicolumn{1}{c}{$\begin{array}{c}\text { Oil - production } \\
\text { (barrels/day) }\end{array}$} & Year \\
$\mathbf{1}$ & Estados Unidos & $15,647,000$ & 2017 \\
$\mathbf{2}$ & Arabia Saudita & $12,090,000$ & 2017 \\
$\mathbf{3}$ & Rusia & $11,210,000$ & 2017 \\
$\mathbf{4}$ & Canadá & $4,958,000$ & 2017 \\
$\mathbf{5}$ & China & $4,779,000$ & 2017 \\
$\mathbf{6}$ & Irán & $4,695,000$ & 2017 \\
\cline { 2 - 4 } $\mathbf{7}$ & Iraq & $4,455,000$ & 2017 \\
$\mathbf{8}$ & Emiratos Árabes & $3,721,000$ & 2017 \\
$\mathbf{9}$ & Unidos & $3,363,000$ & 2017 \\
\hline $\mathbf{1 0}$ & Krasil & $2,825,000$ & 2017 \\
\hline $\mathbf{1 1}$ & Mexait & $\mathbf{2 , 2 6 0 , 0 0 0}$ & $\mathbf{2 0 1 7}$ \\
\hline
\end{tabular}

Tabla 1 Producción diaria de barriles de petróleo y otros líquidos de cada país en el año 2017

Fuente: U.S. Energy Information Administration (2018)

Table 2 presents the average daily production of barrels of crude oil by country in 2017. A total of 127 countries were identified by the U.S. Energy Information Administration as producers and sorted in descending order according to their production.

\begin{tabular}{|c|c|c|c|}
\hline $\mathbf{N}^{0}$ & Country & $\begin{array}{c}\text { Dry natural gas - } \\
\text { production (cubic feet / day) }\end{array}$ & Year \\
\hline 1 & Estados Unidos & $27,291,000,000,000$ & 2017 \\
\hline 2 & Rusia & $23,508,000,000,000$ & 2017 \\
\hline 3 & Irán & $7,577,000,000,000$ & 2017 \\
\hline 4 & Qatar & $5,875,000,000,000$ & 2017 \\
\hline 5 & Canadá & $5,618,000,000,000$ & 2017 \\
\hline 6 & China & $5,152,000,000,000$ & 2017 \\
\hline 7 & Noruega & $4,375,000,000,000$ & 2017 \\
\hline 8 & Arabia Saudí & $3,859,000,000,000$ & 2017 \\
\hline 9 & Australia & $3,717,000,000,000$ & 2017 \\
\hline 10 & Argelia & $3,302,000,000,000$ & 2017 \\
\hline 11 & Turkmenistán & $2,735,000,000,000$ & 2017 \\
\hline 12 & Indonesia & $2,546,000,000,000$ & 2017 \\
\hline 13 & Malasia & $2,454,000,000,000$ & 2017 \\
\hline 14 & $\begin{array}{l}\text { Emiratos } \\
\text { Árabes Unidos }\end{array}$ & $2,190,000,000,000$ & 2017 \\
\hline 15 & Uzbekistán & $1,840,000,000,000$ & 2017 \\
\hline 16 & Egipto & $1,796,000,000,000$ & 2017 \\
\hline 17 & Países Bajos & $1,601,000,000,000$ & 2017 \\
\hline 18 & Nigeria & $1,571,000,000,000$ & 2017 \\
\hline 19 & Reino Unido & $1,487,000,000,000$ & 2017 \\
\hline 20 & Argentina & $1,445,000,000,000$ & 2017 \\
\hline 21 & Pakistán & $1,379,000,000,000$ & 2017 \\
\hline 22 & Tailandia & $1,363,000,000,000$ & 2017 \\
\hline 23 & $\begin{array}{ll}\text { Trinidad } & \mathrm{y} \\
\text { Tobago } & \end{array}$ & $1,297,000,000,000$ & 2017 \\
\hline 24 & Mexico & $1,115,000,000,000$ & 2017 \\
\hline 25 & India & $1,114,000,000,000$ & 2017 \\
\hline
\end{tabular}

Tabla 2 Producción diaria de pies cúbicos de gas natural seco de cada país en el año 2017

Fuente: U.S. Energy Information Administration (2018) 
Also, Table 3 shows the daily production of dry natural gas by country (which sums a total of 95), in cubic feet, according to data taken from the U.S. Energy Information Administration (2018).

It is estimated that this year the availability of oil in the world will be reduced, due to an agreement between the member countries of the Organization of Petroleum Exporting Countries (OPEC) and other allied countries, including Russia, with the purpose of mitigate the price drop that crude oil had in October 2018, since Ixchel Castro, manager for Latin America of Petroleum and Refining Markets of the consulting firm WoodMackenzie stated: "Now, for 2019, we are facing a scenario in which oil supply will grow above demand. "

\section{National context}

Mexico occupies the eleventh place in the production of crude oil and the twenty-fourth in dry natural gas, making it one of the main suppliers of hydrocarbons worldwide. (US Energy Information Administration, 2018).

The exploitation of a relatively new type of resource has caused the progressive decline in US oil production to reverse.

Mexico's crude oil production will continue to fall in the short and medium term, according to the Mexican Association of Hydrocarbons Company.

\section{Intellectual capital}

Intellectual capital, which is currently understood as:

"The set of individual or collective knowledge that can substantially increase the production of material and spiritual goods. It is today the greatest source of wealth for organizations. It is comprised of all the intangible assets of an organization or a place that, despite not being reflected in the traditionally used financial statements, generate value or has the potential to generate it." (Garcés, 2011).

\section{Methodology to develop}

\section{Emergence of the idea}

In this investigation, in order to establish and ensure the efficiency of the thematic unit, we have structured the delimitation of the idea that guides this study, as shown in Figure 1.

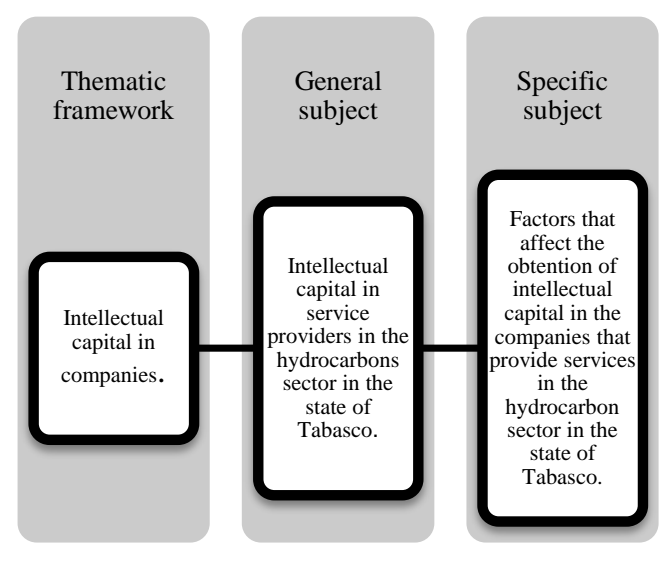

Figure 1 Thematic scheme for the delimitation of the subject

Source: Self Made

The thematic framework addressed in the present paper is intellectual capital in companies, so that research is oriented towards the adoption of intellectual capital within organizational systems, given the international relevance of intangible assets as a new economic base. As a general research topic, we establish the study of intellectual capital in the companies that provide services in the hydrocarbon sector in the state of Tabasco, since nationally and statewide (Tabasco), its main economic force is oil mining.

Finally, the specific issue addressed by the study consists of the factors that influence the obtention of intellectual capital in the companies that provide services in the hydrocarbon sector in the state of Tabasco, since we work under the premise that the intellectual capital approach as a new source of wealth generation in the state has not been adopted, an aspect found during the development of the research protocol.

\section{Applied Tools}

Based on the perception of sector experts, the method we used is: structural analysis, which is also part of the design of the double entry matrix, structured with the impact factors in the industry studied and the incidence that each one maintains over the rest. $\mathrm{P}$ 
The matrix offers a broad vision of the interaction that exists between the factors, quantifying the levels of motility and dependence of one factor with respect to others, which outlines its graphic location within a Cartesian plane, classifying the quadrants by zone. According to the methodology, the quadrants are described below:

\section{Quadrant I Conflict Zone}

Quadrant II Power Zone

Quadrant III Zone of autonomous problems

Quadrant IV Departure Zone

In order to determine the factors that belong to each zone, we consider their level motility and dependence with respect to the others; the percentage value must be obtained by factor of the two aforementioned items. These values are compared with the parameter determined by the proportional equivalent of the total number of factors. According to the area in which the factor is located, the role it plays is defined.

Once the above is established, the scenario design is concluded, which is used to outline the diagnosis of the current situation of the sector, based on the analytical criteria assessed by the author, who proposes a comprehensive development model that counteracts the critical points identified in the research, in order to achieve the competitiveness of the industry under study.

In addition, the conclusions inferred by the author of the research, according to the results obtained during its development, are grossly expressed, as well as the pertinent recommendations for the implementation of the proposal.

\section{Conclusions}

This research paper reflects a pragmatic and synchronous line of work, which is why, like Reed, Lubatkin and Srinivasan (2006), it offers a vision of the company based on intellectual capital and is oriented towards the identification and study of the variables that affect the obtention of intellectual capital in Mexican organizations, starting from the general (the context variables), to the particular (specific incidence factors that are immersed in the context variables).
Currently, the suppliers of the oil industry face a great challenge, due to the great competition that exists in this sector and the political variables. We present the methodology followed in the present investigation, since it is still ongoing.

\section{References}

Agencia de Seguridad, Energía y Ambiente. (December 04, 2017). Normatividad ASEA. Retrieved from https://www.gob.mx/asea/acciones-yprogramas/leyes-y-normas-del-sector

Comisión Nacional de Hidrocarburos. (2018). Licitaciones y contratos. Retrieved from https://portal.cnih.cnh.gob.mx/dashboardempresas.php

Comisión Nacional de Hidrocarburos. (2018). ¿Sabes cómo se encuentran adjudicados los 107 contratos que hasta el día de hoy lleva la \#CNH?. [Infografía]. Retrieved from https://www.linkedin.com/feed/update/urn:li:act ivity:6453038899177541632

Comisión Nacional de Hidrocarburos. (06 de noviembre, 2018). CNH ha celebrado 18 convenios de colaboración con Universidades y Centros de Investigación. Retrieved from https://portal.cnih.cnh.gob.mx/estadisticas.php

Drucker, P. (2006). La administración; la organización basada en la información; la economía y la sociedad. Editorial Norma. Bogta. Colombia [Versión Electrónica], Retrieved from http://www.scribd.com/.../Examinacion-yEvaluacion-de-Los-Aprendizajes

Garcés, Roberto. (2011). La composición del capital intelectual. Una valoración sociológica. Acta Universitaria. 21. 5-11. https://www.researchgate.net/publication/23703 4609_La_composicion_del_capital_intelectual_ Una_valoracion_sociologica

Hernández Sampieri, R., Fernández Collado, C. y Baptista Lucio M. P. (2014). Metodología de la investigación. Mexico City, Mexico: McGRAW-HILL. 
Hernández Ramírez, J. (27 de julio del 2017). Podrían quedar fuera 300 empresas tabasqueñas por no cumplir los lineamientos. Diario Presente. Retrieved from https://www.diariopresente.mx/tabasco/podrian -quedar-fuera-300-empresas-tabasquenas-porno-cumplir-los-lineamientos/196126

Joya, R., Gámez, L., Ortiz, M. y Gálvez A. (2015). Medición del capital intelectual en empresas mexicanas. Retos de la dirección, 9(1), 79-95. Retrieved from http://scielo.sld.cu/pdf/rdir/v9n1/rdir04115.pdf

Ochoa Hernández, M. L., Prieto Moreno, M. B. y Santidrián Arroyo, A. (2012). Una revisión de las principales teorías aplicables al capital intelectual. Revista nacional de administración, 3(2), 35-48. Retrieved from file:///Users/mayrafuentes/Documents/Maestria/ Tesis\%20maestri\%CC\%81a/una\%20revisio\%C C\%81n\%20de\%20las\%20peincipales\%20teori $\%$ CC $\% 81$ as\%20aplicables\%20al\%20capital\%2 0intelectual.pdf

Rosales, R. A. (04 de septiembre del 2018). Campeche ocupa el primer lugar en participaciones. El Economista. Retrieved from https://www.eleconomista.com.mx/estados/Ca mpeche-ocupa-el-primer-lugar-enparticipaciones-20180905-0001.html

U.S. Energy Information Administration. (2018). International Energy Statistics. Retrieved from https://www.eia.gov/beta/international/

Villegas, E., Hernández, M. y Salazar, B. (2015). La medición del capital intelectual y su impacto en el rendimiento financiero en empresas del sector industrial en México. Contaduría y Administración, 62(2017), 184-206. Retrieved from

http://www.scielo.org.mx/pdf/cya/v62n1/01861042-cya-62-01-00184.pdf

Wriston, W. B. (1992). The Twilight of Sovereignty: How the Information Revolution is Transforming Our World. New York, U.S.A.: Charles Scribner's Sons. 